\title{
Tests of multiple molecular markers for the identification of Great Spotted and Syrian Woodpeckers and their hybrids
}

\author{
Jerzy Michalczuk • Allan D. McDevitt • Tomasz D. Mazgajski • \\ Tomasz Figarski - Mihaela Ilieva $\cdot$ Małgorzata Bujoczek • \\ Paweł Malczyk $\cdot$ Lukasz Kajtoch
}

Received: 10 September 2013/Revised: 12 November 2013/Accepted: 6 January 2014/Published online: 22 January 2014

(C) The Author(s) 2014. This article is published with open access at Springerlink.com

\begin{abstract}
Great Spotted and Syrian Woodpeckers (Dendrocopos major and D. syriacus) are known to hybridize in nature; however, the extent of this phenomenon is not known due to difficulties in hybrid detection based on plumage analyses. Here, we tested five markers (one mitochondrial and four nuclear) and a set of six microsatellite loci for the identification of these two Woodpeckers and their hybrids. Sequencing of DNA from 26 individuals of both Woodpeckers from different parts of their ranges: one allopatric (D. major; Norway) and two sympatric (Poland and Bulgaria) showed that both species can be clearly separated based on all sequence markers. The highest number of fixed nucleotide sites were found in the mtDNA control region and intron 5 of the transforming growth factor. Analyses of microsatellite data distinguished the two species, but all loci showed a large number of common alleles and their utility in identifying hybrids is
\end{abstract}

Electronic supplementary material The online version of this article (doi:10.1007/s10336-014-1040-1) contains supplementary material, which is available to authorized users.

\section{J. Michalczuk}

Department of Agrobiology and Environmental Protection, University of Rzeszow, Zelwerowicza 4, 35-601 Rzeszow, Poland

\section{A. D. McDevitt}

School of Biology and Environmental Science, University College Dublin, Belfield, Dublin 4, Ireland

\section{T. D. Mazgajski}

Museum and Institute of Zoology, Polish Academy of Sciences, Wilcza 64, 00-679 Warsaw, Poland

T. Figarski $\cdot$ Ł. Kajtoch $(\bowtie)$

Institute of Systematics and Evolution of Animals, Polish Academy of Sciences, Sławkowska 17, 31-016 Cracow, Poland e-mail: lukasz.kajtoch@gmail.com therefore doubtful. According to the DNA sequence analyses, 2 out of 18 specimens within the sympatric range in Poland were identified as possible hybrids, most probably paternal backcrosses. Moreover, both hybrids are from synantropic populations (settled in cities), whereas none of the D. major sampled in forests and in its allopatric range (Norway) showed signs of an intermixed genotype. Further research on hybridization and introgression in woodpeckers is undoubtedly needed and could be useful for understanding ecological and ethological interactions among these species, particularly for D. syriacus, which is relatively rare in Europe.

Keywords Mitochondrial DNA · Microsatellites · Hybridization - Picidae - Dendrocopos major . Dendrocopos syriacus

M. Ilieva

Institute of Biodiversity and Ecosystem Research, Bulgarian Academy of Sciences, 2 Gagarin St, 1113 Sofia, Bulgaria

M. Ilieva

Centre for Animal Movement Research, Department of Biology, Lund University, Ecology Building, 22362 Lund, Sweden

\section{Bujoczek}

Department of Zoology and Wildlife Management, Faculty of Forestry, Forest Biodiversity Institute, University of Agriculture, al. 29 Listopada 46, 31-425 Cracow, Poland

P. Malczyk

ul. Graniczna 1, 32-545 Psary, Poland 


\section{Zusammenfassung}

\section{Multiple molekulare Marker zur Identifizierung des Buntspechts, des Blutspechts und ihrer Hybriden}

Buntspechte und die Blutspechte (Dendrocopos major und D. syriacus) sind dafür bekannt, in der Natur zu hybridisieren, aber das Ausmaß dieses Phänomens ist aufgrund von Schwierigkeiten bei der Erkennung von Hybriden auf der Basis von Gefiederanalysen nicht bekannt. Wir testeten fünf verschiedene molekulare Marker (einen mitochondrialen und vier nukleare) und einen Satz von sechs Mikrosatelliten-Loci für die Identifizierung dieser beiden Spechtarten und ihren Hybriden. Die Sequenzierung der DNA von 26 Individuen beider Arten aus verschiedenen Regionen ihres Verbreitungsgebietes, eine allopatrische $(D$. major - Norwegen) und zwei sympatrische (Polen und Bulgarien) zeigten auf, dass beide Arten auf der Basis von allen Sequenzmarkern eindeutig identifiziert werden können. Die größte Anzahl fester Nukleotid-Stellen wurde in der mtDNA-Kodierungsregion und im Intron 5 des transformierenden Wachstumsfaktors gefunden. Die Daten aus der Mikrosatellitenanalyse ermöglichen es zwar, die beiden Arten zu unterscheiden, aber alle Loci zeigten eine große Anzahl von gemeinsamen Allelen, wodurch ihr Nutzen bei der Identifizierung von Hybriden zweifelhaft ist. Die DNASequenzanalyse zeigte, dass 2 von 18 Proben aus dem sympatrischen Areal in Polen als mögliche Hybride identifiziert wurden und wahrscheinlich aus väterlichen Rückkreuzungen stammen. Darüber hinaus sind beide Hybriden aus städtischen Populationen, während keiner der D. major in Wäldern und in seinem allopatrischen Verbreitungsgebiet (Norwegen) Anzeichen eines vermischten Genotyps zeigte. Weitere Untersuchungen der Hybridisierung und Introgression bei Spechten sind zweifellos notwendig und hilfreich für das Verständnis der ökologischen und ethologischen Interaktionen zwischen diesen Arten, insbesondere für D. syriacus, welcher in Europa relativ selten vorkommt.

\section{Introduction}

Hybridization is caused by incomplete or ineffective reproductive isolation mechanisms. Most examples of interspecific breeding concern closely related species pairs or allospecies within superspecies groups (e.g., Randler 2002). These species are likely to be genetically compatible and often have similar life histories and behavior that enables mating. Hybridization occurs often in situations related with range and abundance shifts. One possibility is when two species came into contact at the borders of their ranges. The second scenario is when one of the two species expands its range (naturally or via introduction) and is much less common than the local relative in the new area. The third example may happen when at least one of the species seriously declines in part of its range. Hence, in all these situations, the pressure of breeding needs may force an individual of one species (less common) to accept an individual of the other species as a mate, resulting in hybrid offspring (Hubbs 1955; Randler 2002; Aliabadian and Nijman 2007). However, there are also examples of continuing hybridization between two species which become similarly common in some areas (e.g., Great Spotted Dendrocopos major and Syrian Woodpeckers $D$. syriacus; Gorman 1997).

Interspecific breeding and hybrids are hard to detect and study, but such situations are relatively common within the order of birds (Aves), as almost $20 \%$ of bird species can hybridize (Panov 1989; Grant and Grant 1992; Randler 2002; McCarthy 2006). Among woodpeckers (family Picidae), several species pairs are known to hybridize (Short 1982; Randler 2002). Most examples concern strictly American genera: Campephilus, Sphyrapicus, Melanerpes, Celeus, Centurus, Veniliornis, and Picumnus (Selander and Giller 1959; Johnson and Johnson 1985; Seneviratne et al. 2012; Fuchs et al. 2013). Examples are also known within African Campethera woodpeckers (Short 1982), Picus (viridis/canus) in Eurasia (Beuch 2012), Dryocopus (schulzi/linneatus) in South America (Madroño Nieto and Pearman 1992), and among a few Picoides species in North America (Miller 1955; Short 1982). Within the genus Dendrocopos, the most often hybridizing woodpecker is probably the Great Spotted Woodpecker as it can mate and breed with: Syrian Woodpecker (Winkler 1971; Skakuj and Stawarczyk 1994; Gorman 1997; Dudzik and Polakowski 2011), Sind Woodpecker D. assimilis (Short 1982), and White-backed Woodpecker D. leucotos (Laine 1993). Hybrids between $D$. syriacus and D. assimilis are also known (Short 1982). Dendrocopos major and D. syriacus are considered as sister species, and they differ in some morphological (plumage), behavioral (e.g., calls), and ecological (habitat preferences) characteristics. D. major is the most common woodpecker in Eurasia, and its range covers almost the whole temperate zone. Dendrocopos syriacus originally inhabited only south-west Asia. However, since the end of the nineteenth century, it has expanded into the Balkans (Reister 1894; Kohl 1954), and in the second half of the twentieth century, it has reached central (Keve 1955) and eastern Europe (Marisova 1964) as far north as Poland (Ciosek and Tomiałojć 1982). This species is still relatively rare in Europe (BirdLife International 2012) and is protected under the Bird Directive of European Union (2009/ 147/EC). In central Europe, D. major and D. syriacus are sympatric (supplementary Fig. 1), but they rarely breed in 
the same areas. Dendrocopos major is generally a forestdwelling species (e.g., Michalek and Miettinen 2003), whereas $D$. syriacus inhabits parks, gardens, and scattered riparian forests (Michalczuk and Michalczuk 2011; Kajtoch 2012; Ciach and Fröhlich 2013). Hybrids of these two woodpeckers were first noted in Hungary (Keve 1955; Gorman 1997). During the last 3 decades (1980-2010), 17 observations of mixed pairs or hybrids were documented in Poland (Dudzik and Polakowski 2011); however, this count is probably highly underestimated as several such examples have been noted in Poland in recent years (http:// clanga.com/). These data suggest that hybridization between the species may not be a rare phenomenon and that hybrid individuals should be present in sympatric populations. Winkler (1971) and Short (1982) suggested a moving hybrid zone between these two species in Europe while D. syriacus expands into central Europe, but the interbreeding tended to decline rapidly once $D$. syriacus became established. This is probably a misconception, as hybrids are being found in central Europe in areas with abundant D. syriacus populations (Gorman 1997). Identification of hybrids of $D$. major and $D$. syriacus was previously described based on plumage differences (Skakuj and Stawarczyk 1994; Gorman 2004; Dudzik and Polakowski 2011, see also supplementary Fig. 2). However, these studies did not include identification of possible backcrosses and did not show any information about hybrid frequency in mixed populations. Hybrids cannot always be detected and identified using just morphological features (Senn and Pemberton 2009). Morphological variables can allow for the identification of first-generation (F1) hybrids but, on the other hand, backcrosses (hybrids in further generations) are often indistinguishable from one of the parent species (Senn and Pemberton 2009).

Nowadays, advances in molecular techniques allow for species and hybrid identification based on DNA analyses. The utility of mitochondrial DNA, most often used in phylogenetics and phylogeographic studies and also for species barcoding (Hebert et al. 2003), is limited for hybrid identification because mtDNA alone cannot identify hybrid origin and DNA introgression, as it shows only maternal inheritance (Wilson et al. 1985), and cannot be used to identify male-mediated gene flow. However, it can be used to identify the maternal species in F1 hybrids (McDevitt et al. 2009). More useful, however, is nuclear DNA because hybrids and their backcrosses carry this from both ancestral species, and hybridization and introgression can be detected using nuclear markers (Avise and Ball 1990; Weins and Servedio 2000). The utility of nuclear markers for identification of species and their hybrids has been shown for introns (e.g., Pacheco et al. 2002; Nadachowska and Babik 2009), single nucleotide polymorphisms (SNP; e.g., Väli et al. 2010; Hohenlohe et al. 2011), and microsatellites (e.g., Gay et al. 2007; Väli et al. 2010). A combined set of nuclear and mitochondrial markers may be the best option for species and their hybrids identification, especially in birds, when hybridizing species diverged recently and share a high proportion of alleles (e.g., Gay et al. 2007; Väli et al. 2010).

There is high disproportion between genetic studies on $D$. major and $D$. syriacus, as the phylogeography of only $D$. major has been described (but only based on mtDNA; Zink et al. 2002; Garcia-del-Rey et al. 2007; McDevitt et al. 2011; Perktas and Quintero 2013), whereas nothing is known about the population genetics of $D$. syriacus. In addition, microsatellites have not been used for population studies on either of these two species thus far. This lack of knowledge about the genetics of $D$. syriacus and molecular differences with $D$. major has hindered the identification of their hybrids and backcrosses.

The main aim of this research was to test the utility of several molecular markers (one mitochondrial, four nuclear introns, and a set of microsatellite loci) for the identification of D. major and D. syriacus and their possible hybrids. As the extent of hybridization between these two species is not known, it seems important to establish a method to indentify their hybrids. This will ultimately help in understanding the mechanisms of their evolutionary, ecological, and ethological interactions.

\section{Methods}

Sampling

Samples of woodpecker tissues were collected from other research and ringing projects, and were taken from specimens delivered to museum collections (Museum and Institute of Zoology Polish Academy of Science and Museum of Natural History in Institute of Systematics and Evolution of Animals PAS), during the last 5 years (2009-2013). Details are presented in Table 1. Several individuals of $D$. major and $D$. syriacus from different localities were gathered, as well as other woodpecker species as outgroups (all other European Dendrocopos species and the Three-toed Woodpecker Picoides tridactylus). Sampling was designed to collect specimens of D. major from sympatric (Poland) and allopatric (Norway) populations. D. syriacus was collected from a sympatric population on the verge of species expansion (Poland) and from the core of its range in Europe (Bulgaria) where it is parapatric with $D$. major. Two specimens of possible hybrid origin (according to plumage characteristics) were used in the analyses. One young bird found dead in Krakow city in 2009, whose plumage was most syriacus-like but some characters suggested hybrid origin; however, its body 
Table 1 Woodpecker samples used in study, localization of sampling sites and source of tissue used for DNA extraction

\begin{tabular}{|c|c|c|c|c|c|}
\hline Fenotype & Specimen symbol & Locality & Country & Tissue & No of specimens \\
\hline D. major & NO1-4 & Ostfold vicinity & Norway & Feather & 4 \\
\hline D. major & MA & Mazury District & Poland & Feather & 1 \\
\hline D. major & KR1 & Krakow city & Poland & Muscle & 1 \\
\hline D. major & SM & Sudeten Mts. & Poland & Feather & 1 \\
\hline D. major & SL & Slonsk vicinity & Poland & Feather & 1 \\
\hline D. major & $\mathrm{CA}$ & Carpathian Mts. & Poland & Feather & 1 \\
\hline D. major & NP & Niepołomice Forest & Poland & Muscle & 1 \\
\hline D. major & RA1-2 & Radom city & Poland & Feather & 2 \\
\hline D. major & WA $1^{\mathrm{a}}$ & Warsaw city & Poland & Feather & 1 \\
\hline D. syriacus & $\mathrm{KR}^{\mathrm{a}}, \mathrm{KR} 4$ & Krakow city & Poland & Muscle & 2 \\
\hline D. syriacus & WA2 & Warsaw city & Poland & Muscle & 1 \\
\hline D. syriacus & ZA1-5 & Zamosc vicinity & Poland & Feather & 5 \\
\hline D. syriacus & GM & Warsaw vicinity & Poland & Egg shell & 1 \\
\hline D. syriacus & BU1-4 & Kalimok station & Bulgaria & Blood spot, feather & 4 \\
\hline D. leucotos & & Carpathian Mts. & Poland & Muscle & 1 \\
\hline D. minor & & Krakow vicinity & Poland & Feather & 1 \\
\hline D. medius & & Krakow vicinity & Poland & Feather & 1 \\
\hline P. tridactylus & & Carpathian Mts. & Poland & Feather & 1 \\
\hline
\end{tabular}

${ }^{a}$ Birds with morphological characteristics suggestive of hybrid origin

was in an advanced stage of decomposition and not all characters could be determined (Wójcik J.D.). The second bird (young male) was caught in Warsaw city (2012) and its plumage was generally like $D$. major but some features suggested hybrid origin (Elas M.). Tissues were either preserved in ethanol (muscle) or absorptive paper (blood spots) in a freezer, or kept dry in plastic bags (feathers, egg shells).

\section{DNA sequence analyses}

DNA extraction was performed either using Nucleospin Tissue kit (Macherey-Nagel, Düren, Germany) or, for older samples not directly preserved and those of small starting amounts, using Sherlock AX DNA isolation kit (A \& A Biotechnology, Gdynia, Poland). Sequences of three woodpecker autosomal introns: beta-fibrinogen gene (intron 7) (BF7), myoglobin gene (intron 2) (MG2), transforming growth factor (intron 5) (TGF5), and one Z-linked intron-brahma gene (intron 15) (BR15) were downloaded from GenBank (http://www.ncbi.nlm.nih.gov/ genbank/) and used for designing primers using PRIMER 3 (http://bioinfo.ut.ee/primer3-0.4.0/). Primers were located within regions conserved in the Dendrocopos genus. Primers for mitochondrial control region (CR) were as in McDevitt et al. (2011). Characteristics of primers used in this study are presented in supplementary table 1. Amplification was done using Qiagen PCR Core Kit (Hilden, Germany). The cycling profile for the PCR was: $95^{\circ} \mathrm{C}$ for
4 min, 35 cycles of $95{ }^{\circ} \mathrm{C}$ for $30 \mathrm{~s}, 54{ }^{\circ} \mathrm{C}$ for $1 \mathrm{~min}, 7{ }^{\circ} \mathrm{C}$ for $2 \mathrm{~min}$, and a final extension period of $72{ }^{\circ} \mathrm{C}$ for $10 \mathrm{~min}$. After purification, PCR fragments (NucleoSpin Extract II; Macherey-Nagel) were sequenced using the BigDye Terminator v.3.1 Cycle Sequencing Kit (Applied Biosystems, Foster City, USA) and an ABI 3100 Automated Capillary DNA Sequencer. All sequences were deposited in GenBank (accession numbers KF445345-KF445387a).

Sequences were checked and aligned using BioEdit v.7.0.5.2 (Hall 1999) and ClustalX (Thompson et al. 1997). Mitochondrial haplotypes were identified and standard genetic indices such as number of polymorphic and segregating sites, number of haplotypes, haplotype diversity, and nucleotide diversity for D. major and D. syriacus were computed using the program DnaSP v.5 (Librado and Rozas 2009). Mitochondrial and TGF5 haplotype networks for D. major and D. syriacus samples were constructed using the Median-Joining network method (Bandelt et al. 1999) in the Network 4.6.1.0. software (http://www.fluxusengineering.com/). Nuclear genotypes as well as nuclear polymorphic and segregating sites were counted manually, while alleles numbers were not estimated as within nuclear introns were found heterozygous nucleotide positions and alleles could not be determined precisely without cloning. Simple Neighbor-Joining (NJ) phylogenetic trees were constructed separately on mtDNA and concentrated nuclear DNA sequences using MEGA v.5 (Tamura et al. 2011). To estimate utility of particular markers for assignment of individuals to D. major or D. syriacus, 
numbers of discriminating sites (in which different nucleotides were fixed in each of these two species) were determined.

\section{Microsatellite analyses}

Five microsatellite loci developed for D. leucotos (Ellegren et al. 1999) were chosen according to previous cross-species amplification success in both $D$. major or D. syriacus: Dlu1, Dlu3, Dlu4, Dlu5, and Dlu6 (Rutkowski et al. 2006). Moreover, three loci developed for D. medius (Vila et al. 2008) were chosen on the basis of cross-species amplification efficiency in D. major (Rutkowski, unpublished): DMC111, DMC115, and DMC118. All these eight loci were preliminary tested and all gave PCR products for both D. major or D. syriacus. However, DMC118 also gave many other additional products and there were problems with Dlu4 genotyping (due to possible amplification of duplicated locus). These two loci were excluded from further analyses. Six loci were amplified in two multiplexes using fluorescent labeling primers and Qiagen multiplex PCR master mix (Qiagen). The cycling scheme was as follows: $94{ }^{\circ} \mathrm{C}$ for $15 \mathrm{~s}$ followed by 40 cycles of $94{ }^{\circ} \mathrm{C}$ for $20 \mathrm{~s}, 55^{\circ} \mathrm{C}$ for $90 \mathrm{~s}$, and $72{ }^{\circ} \mathrm{C}$ for $30 \mathrm{~s}$; the final extension was at $72{ }^{\circ} \mathrm{C}$ for $10 \mathrm{~min}$. PCR products were electrophoresed on an ABI 3130xl Genetic Analyser with GeneScan 500 LIZ size standard (Applied Biosystems). Allele sizes were determined using GeneMapper software (Applied Biosystems).

Number of alleles, allelic richness, and the observed and expected heterozygosities were calculated with Arlequin 3.5 and FSTAT (Goudet 2002; Excoffier and Lischer 2010). Tests of departures from Hardy-Weinberg equilibrium, and tests of linkage disequilibria were performed using GENEPOP (Rousset 2008).

Hybridization was tested between species using a Bayesian admixture analysis approach implemented in STRUCTURE v.2.2 (Pritchard et al. 2000; Vaha and Primmer 2006; Sanz et al. 2009) to obtain individual genetic assignment to either D. major or D. syriacus based on the six microsatellite loci. We assumed the presence of two genetic clusters/species $(K=2$; McDevitt et al. 2009; Senn and Pemberton 2009). STRUCTURE was run with 10 independent runs using 500,000 iterations, with a burn-in period of 100,000 iterations. A threshold for hybrid identification was not initially assigned as this can depend on the allele frequency differences between species, and there is also the risk of misidentifying 'pure' individuals as hybrids due to ancestral polymorphism (Senn and Pemberton 2009). This threshold is crucial, and there is always a trade-off between assignment efficiency and accuracy. The selection of this threshold has varied between 0.01 and 0.2 , depending on the hybridization study (McDevitt et al.
2009; Senn and Pemberton 2009; Frantz et al. 2013). In addition, a principal component analysis (PCA) was performed using the adegenet (Jombart 2008) and ade4 (Dray and Dufour 2007) packages in R v.2.12.1 (R Development Core Team 2010). Unlike the previous methods, it does not assume HWE or linkage disequilibrium.

\section{Results}

Sequence markers

The alignment of the control region for all studied woodpeckers revealed that there were no indels present within the D. major, D. syriacus, and D. leucotos group, but some indels were observed between this group and other species. For the nuclear introns, there were small or large indels differentiating the D. major-syriacus-leucotos group from other species, most large indels differentiating $D$. medius and $P$. tridactylus from other Dendrocopos species. Standard mtDNA and nucDNA genetic indices calculated for D. major and D. syriacus are presented in supplementary table 2. Dendrocopos major is much more diverse than $D$. syriacus. Simple NJ trees (supplementary fig. 3) showed that there is uncertainty in woodpecker phylogeny. First, the position of outer taxa (D. minor, D. medius, and $P$. tridactylus) is different with respect to mtDNA and nuclear DNA. Only some nodes have statistical support. In both trees, D. major, D. syriacus, and D. leucotos form a monophyletic cluster (100\% support). However, their position is different depending on the marker type. According to mtDNA $D$. major is a sister species to $D$. leucotos (86\% support), whereas, according to nucDNA, D. major is a sister species to D. syriacus (but only with $61 \%$ support). The haplotype network of mtDNA, and,

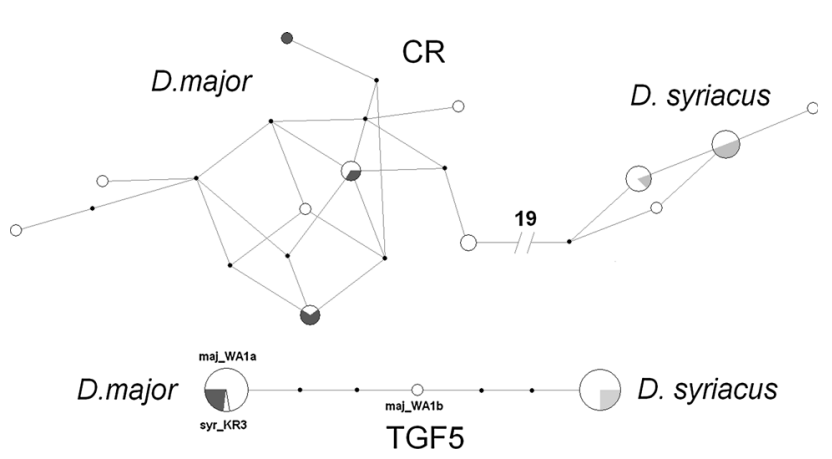

Fig. 1 Haplotype networks of mitochondrial DNA (control region, $C R$ ) and transforming growth factor (intron 5, TGF5) constructed for two Dendrocopos species. White samples from Poland, dark gray Norway, light gray Bulgaria, black dots missing haplotypes, numbers number of mutations in longer branches, syr_KR3 D. syriacus which showed D. major TGF5, maj_WA1a\&b two alleles found in D. major WA1 
Table 2 Polymorphic sites within five DNA markers compared among Dendrocopos major and D. syriacus samples

\begin{tabular}{|c|c|c|c|c|c|}
\hline Specimen & mtDNA control region & Beta-fibrinogen i.7 & Myoglobin i.2 & $\begin{array}{l}\text { Transforming } \\
\text { growth factor i. } 5\end{array}$ & $\begin{array}{l}\text { Brahma } \\
\text { protein i.15 }\end{array}$ \\
\hline maj_NO1 & CGACCACCGTTCTAAGCTGTCAGTAGAGG & TATGACGGGACCACA & GYCMCTCGG & CGCA & $\mathrm{CC}$ \\
\hline maj_NO2 & 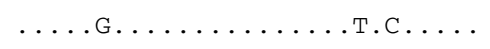 & $\ldots \ldots \ldots \ldots \ldots$ & R...... & $\cdots$ & . \\
\hline maj_NO3 & $\ldots \ldots$ G............... & ..R...R. . G. & $\ldots \ldots \ldots$ & $\ldots$ & $\mathrm{T}$ \\
\hline maj_NO4 & $\ldots \ldots$ G............... & ..R...R.R.G. & $\ldots \ldots \ldots$ & $\ldots$ &. $\mathrm{T}$ \\
\hline maj_MA & 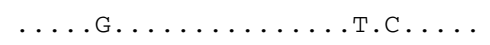 & Y..R.R..Y.RY. & R..... & $\ldots$ &. $\mathrm{T}$ \\
\hline maj_KR1 & $\ldots$ TG.............. & Y.GA. .R . RYYRY . & A.Y..... & $\ldots$ & . \\
\hline maj_SM & $\ldots \ldots$ G.................. & C.GA..A..T.GT. & R...... & $\ldots$ &. $\mathrm{T}$ \\
\hline maj_SL & $\ldots$ G............... & C.GA..A..T.GT. & R..... & $\cdots$ & . \\
\hline maj_CA & 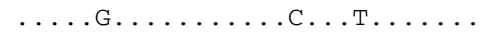 & . GA . A...T.GTC & А... Ү... & $\cdots$ & . \\
\hline maj_NF & $\ldots$. TG..........А. . .... & C.GA..A...T.GT. & A.Y..... & $\ldots$ &. $\mathrm{T}$ \\
\hline maj_RA1 & ....G...C....CA.C..... & $\ldots \ldots \ldots \ldots$ & A. $\ldots \ldots$ & $\ldots$ &. $\mathrm{T}$ \\
\hline maj_RA2 & $\ldots$.G............ CAC.... & .M....RRYR. . & A. . . . . & $\ldots$ &. $\mathrm{T}$ \\
\hline maj_WA1 & ....G........C.C.C.C.... & ....YR.RY.RY. & R...... & Y.Y. & $\mathrm{YT}$ \\
\hline syr_KR3 & TACAT.TTT. .TC.GAT. ACTT. . GATAA & . .GARTARK.T.GT. & ..Y.G.C. & $\ldots$ & . \\
\hline syr_KR4 & TACATGTTT. .TC.GAT.ACTT. .GATAA & . GARTA...T.GT. & $\ldots \ldots \mathrm{CK}$ & TATG & $\mathrm{TT}$ \\
\hline syr_ZA1 & TACAT.TTT. .TC.GAT.ACTT. .GATAA & . GA.TA...T.GT. & $\ldots \ldots \mathrm{CK}$ & TATG & $\mathrm{TT}$ \\
\hline syr_ZA2 & . ACAT. TTT . .TC.GAT. ACTT. . GATAA & .GA.TA...T.GT. & $\ldots \ldots c$. & TATG & T. \\
\hline syr_ZA3 & .АСAT.TTT..TC.GAT.ACTT. .GATAA & .GA.TA...T.GT. & $\ldots \ldots c$. & TATG & T. \\
\hline syr_ZA4 & TACAT.TTT. .TC.GAT.ACTT. .GATAA & . GA.TA... T.GT. & $\ldots \ldots c$. & TATG & $\mathrm{TT}$ \\
\hline syr_ZA5 & . ACAT. TTT . TC.GAT. ACTT . GATAA & .GA.TA..T.GT. & $\ldots \ldots \mathrm{CK}$ & TATG & $\mathrm{TT}$ \\
\hline syr_GM & TACAT.TTT. .TC.GAT. ACTTA. GATAA & . GARTA...T.GT. & $\ldots \ldots \mathrm{CK}$ & TATG & $\mathrm{TT}$ \\
\hline syr_WA2 & .ACAT.TTT. .TC.GAT. ACTT. .GATAA & . GARTA...T.GT. & $\ldots \ldots \mathrm{CK}$ & TATG & $\mathrm{TT}$ \\
\hline syr_BU1 & TACAT.TTT. .TC.GAT.ACTT. . GATAA & .GA.TA... T.GT. & $\ldots \ldots c$. & TATG & $\mathrm{TT}$ \\
\hline syr_BU2 & TACAT.TTT. .TC.GAT.ACTT. . GATAA & . GA.TA...T.GT. & $\ldots \ldots c$. & TATG & $\mathrm{TT}$ \\
\hline syr_BU3 & . АCAT.TTT. .TC.GAT. ACTT. .GATAA & ..KATTA...T.GT. & $\ldots \ldots \mathrm{MCK}$ & TATG & $\mathrm{TT}$ \\
\hline syr_BU4 & TACAT.TTT. .TC.GAT.ACTT. . GATAA & .WGA. TA. . T. GT. & $\ldots \ldots \mathrm{CK}$ & TATG & $\mathrm{TT}$ \\
\hline Dns & 20 & 1 & 1 & 4 & 1 \\
\hline
\end{tabular}

Dns number of discriminating (fixed) nucleotide sites

separately, TGF5 constructed for D. major and D. syriacus, showed that both species belong to separate clades (Fig. 1). Dendrocopos major was more diverse (8 haplotypes found in 13 individuals) than D. syriacus (3 haplotypes in 13 individuals). In D. major and D. syriacus, there are no clear differentiations between individuals from different areas (for D. major, two haplotypes were shared between Norwegian and Polish populations, and, similarly for $D$. syriacus, two haplotypes were found in both Bulgaria and Poland). There were also some polymorphic nucleotide sites of the nuclear introns within populations of $D$. major and D. syriacus, but these differences were not related to geographic origin.

The most important finding of sequence marker analyses is the determination of their utility for $D$. major and $D$. syriacus discrimination. The best marker for this purpose is undoubtedly the control region, as within 806 bp there are 20 nucleotide positions that discriminate these two species (Table 2). Among nuclear markers, the best is TGF5 as it has four discriminating sites. The other markers have only one discriminating site each. BF7 and MG2 are highly polymorphic; however, most polymorphic sites are not fixed between species and, moreover, many of these sites are heterozygous, whereas in TGF5 and BR15 heterozygous sites are rare. BR15 was the least variable marker.

\section{Microsatellites}

There were 4-7 alleles per locus in D. major and 3-5 in D. syriacus (supplementary table 3 ). Linkage disequilibrium was not detected in any of the studied species, whereas departures from Hardy-Weinberg equilibrium were detected in three loci in D. major and a single locus in $D$. syriacus (supplementary table 3), but these departures likely reflect discrepancies due to the sampling design. Standard genetic indices are presented in Table 2. According to these values, D. major is much more diverse than $D$. syriacus. Both species were separated by the Bayesian 
Fig. 2 Microsatellite results. Upper structure results with a $K$ value of 2 for all studied individuals of Dendrocopos major (dark gray) and D. syriacus (light gray). Lower principal component analysis results for microsatellite genotyping of all studied individuals of Dendrocopos major (gray) and D. syriacus (black). Symbols correspond to individuals (see Table 1)

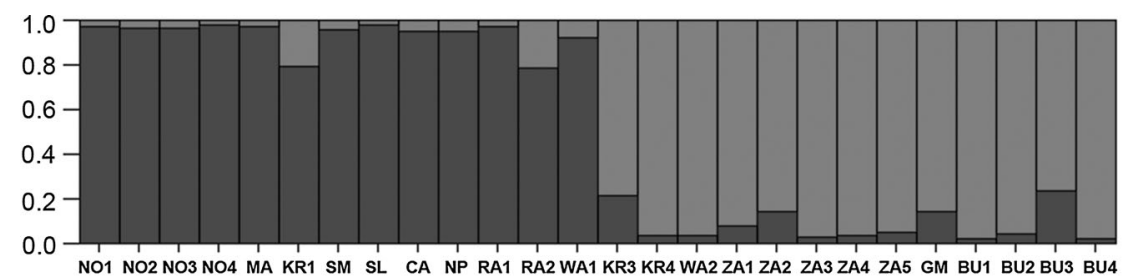

Dendrocopos major Dendrocopos syriacus

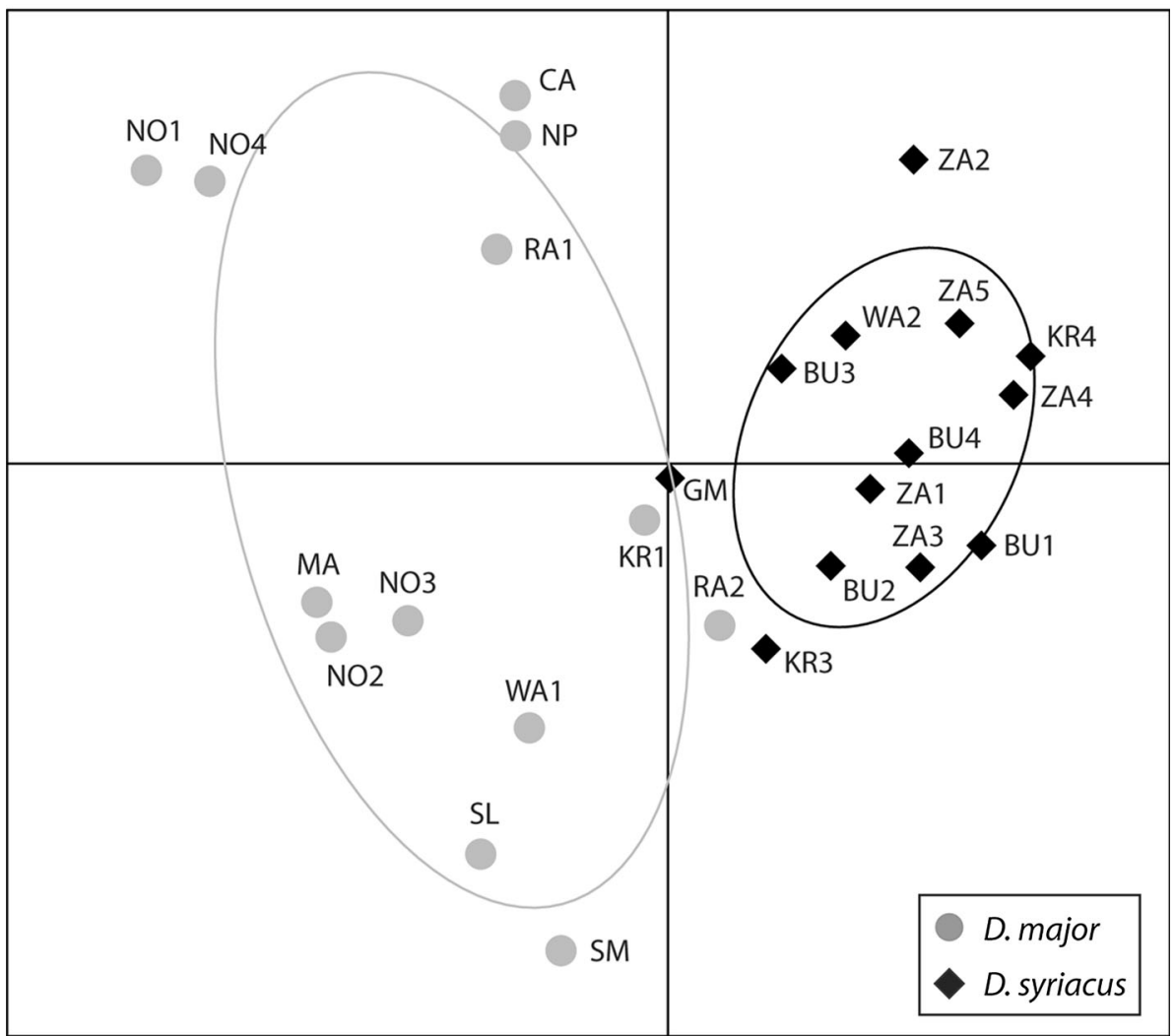

analysis in STRUCTURE (Fig. 2), but this was less clear with the PCA (Fig. 2).

\section{Hybrid detection}

The data from multiple markers suggests that none of the studied woodpecker individuals was an F1 hybrid. There are two individuals where it is probable that the individual in question is a hybrid according to the DNA sequence analyses. One is D. syriacus from Krakow city (KR3), which has "syriacus" CR, but "major" BR15 and TGF5, and the other two nuclear introns (BF7 and MG2) are highly heterozygous. The second bird is $D$. major from Warsaw (WA1), which has "major" CR, whereas according to the nuclear introns, it is highly heterozygous and seems to be intermediate according to TGF5 and BR15. These are the same two individuals that were also considered to be hybrids according to their phenotypes (as described in "Sampling"). The results of the microsatellite analyses were less clear. The allele ranges for all six loci overlapped (supplementary table 3) and neither the Bayesian clustering nor the PCA could confidently assign an individual as being of hybrid origin (Fig. 2). Two $D$. major (KR1 and RA2) and four D. syriacus (KR3, ZA2, GM, BU3) have more than $10 \%$ of their 'genome' assigned to the other species (Fig. 2), with KR1, RA2, $\mathrm{KR} 3$, and BU3 having over $20 \%$ assignment to the other species. According to the PCA, four individuals-two $D$. major (KR1 and RA2) and two D. syriacus (KR3 and GM)-seemed to be somewhat intermediate between the two species (Fig. 2). Dendrocopos major individual WA1 did not appear to be intermediate to the microsatellite analyses (Fig 2).

\section{Discussion}

The genetic analyses support the close relationship between $D$. major and D. syriacus-species which hybridize in nature. These two species belong to a 
superspecies group which includes Asian species: the White-winged Woodpecker D. leucopterus, Sind Woodpecker $D$. assimilis, and Himalayan Woodpecker D. himalayensis (Gorman 2004). Presented phylogenetic trees suggest that $D$. major is closely related with $D$. syriacus (sister species according to nuclear DNA) but also with $D$. leucotos (according to mtDNA; supplementary fig. 3). These three species form a monophyletic clade, but their genetic relationships are not congruent with respect to mtDNA and nuclear DNA (supplementary fig. 3; see also Weibel and Moore 2002; Moore et al. 2006; Rutkowski et al. 2007; Fuchs et al. 2013).

Dendrocopos major and D. syriacus are clearly separated according to the mitochondrial CR (Fig. 2). Within c. $800 \mathrm{bp}$ of CR, 20 nucleotide positions are fixed between these two species. In the studied samples, there were no haplotypes shared between both species. These two species also have genetic differences in all of the studied nuclear introns (both autosomal and Z-linked) but most of polymorphic nucleotide positions are not fixed and both species share many alleles. The exception is TGF5. In BF7, MG2, and BR15, only a single nucleotide position was fixed between these two species, whereas in TGF5, there were four such fixed positions. Regardless of the number of fixed nucleotide positions, all these introns allow for species identification. They also can help in hybrid identification as hybrid individuals (at least F1) should be heterozygous in these fixed nucleotide positions. Indeed, two of the presumed hybrids (KR3 with D. syriacus-like phenotype and WA1 with $D$. major-like phenotype) show either mixed genotypes or high heterozygosity in some of the nuclear introns. However, any of presumed hybrids did not give clear picture of hybrid origin. This can perhaps be interpreted as evidence that these individuals are rather backcrosses as opposed to F1 hybrids. This explanation fits with their morphological characteristics, which were not so straightforward as in the hybrids described by Dudzik and Polakowski (2011). It is important to note that there was no evidence for maternal backcrossing as all woodpeckers with $D$. major phenotype had D. major mtDNA and the same was found in $D$. syriacus. Field observations suggest that hybridization of these two woodpeckers is mostly unidirectional-almost all mixed pairs observed in Poland consist of a male with a D. major phenotype and a female with a D. syriacus phenotype (Dudzik and Polakowski 2011; Michalczuk, Kajtoch, and Malczyk, unpublished data). Moreover, the inference of hybrid status for the two individuals implies that there is no evidence of nuclear introgression in any of the other individuals in the dataset.

Dendrocopos major and D. syriacus can be distinguished based on the set of six microsatellite loci used in this work (Fig. 2). All these loci showed a high frequency of common alleles in both species, which is likely a result of ancestral polymorphism. This may limit the utility of these microsatellites for hybrid identification (Senn and Pemberton 2009). Several individuals showed evidence of admixed genotypes in both the Bayesian analysis in STRUCTURE and the PCA, but not conclusively so. No individuals showed a genotype that could be clearly attributed to a hybrid and the differences observed may reflect normal changes in allele frequencies among the individual species. Therefore, this suite of microsatellites is unlikely to identify potential hybrids between the species. More microsatellite loci (preferably loci which have no overlapping alleles between parent species; Senn and Pemberton 2009) are needed to find a set of microsatellites which could be used for hybrid detection (Vaha and Primmer 2006). The development and characterization of large number of polymorphic microsatellites is possible and efficient via next-generation sequencing techniques (Abdelkrim et al. 2009; Gardner et al. 2011; Kajtoch et al. 2012).

\section{Conclusions}

The data presented here show that it is possible to discriminate between $D$. syriacus and D. major using molecular markers. The best option would be to use two or three sequence markers: CR (whole), TGF5, and BR5 to include a Z-linked locus (these introns could be either sequenced fully or just their SNPs). On the other hand, the six microsatellite loci used in this study did not have enough power to reliably identify hybrids. However, a larger set of loci could be useful for hybrid detection (Vaha and Primmer 2006; Senn and Pemberton 2009).

Two potentially hybrid individuals were identified from the sympatric range of both species in Poland, which is the present boundary of $D$. syriacus' range (according to both phenotype and genotype). It is important to note that both of these potential hybrids are from large cities (Krakow and Warsaw), whereas none of the D. major sampled in forests and in Norway (far from D. syriacus range) showed signs of an intermixed genotype. At the front of $D$. syriacus expansion, woodpeckers may have been expected to hybridize more often (Skakuj and Stawarczyk 1994). However, hybrids were found regularly in areas where $D$. syriacus was established in stable and abundant populations like in Hungary (Gorman 1997), so the range and frequency of hybridization may be more substantial.

This work should be treated as an important contribution for further studies. The tested set of different genetic markers could be used for studies on phylogeography, population genetics, and demography of $D$. syriacus and $D$. major. However, the most interesting topic is the estimation of hybridization and introgression between these two 
species. It is essential to verify how frequent hybrids (and backcrosses) are between $D$. major and $D$. syriacus populations in different parts of their sympatric and allopatric ranges, as such knowledge could be important for understanding ecological and ethological interactions among them. In addition, they could prove useful for the management and conservation of $D$. syriacus.

Acknowledgments We are extremely grateful to Jo Ranke, Joanna D. Wójcik, Tomasz Baziak, Marcin Chrapowicki, and Marek Elas for providing samples for analyses and Katarzyna Dudzik for assistance in microsatellite genotyping. We thank the two anonymous reviewers for their comments on the manuscript. This study complies with the current laws of the country in which they were performed.

Open Access This article is distributed under the terms of the Creative Commons Attribution License which permits any use, distribution, and reproduction in any medium, provided the original author(s) and the source are credited.

\section{References}

Abdelkrim J, Robertson BC, Stanton JL, Gemmel NJ (2009) Fast, cost-effective development of species-specific microsatellite markers by genomic sequencing. Biotechniques 46:185-192

Aliabadian M, Nijman V (2007) Avian hybrids: incidence and geographic distribution of hybridisation in birds. Contrib Zool 76:59-61

Avise JC, Ball RM (1990) Mitochondrial DNA and avian microevolution. Int Ornithol Congr 20(1):514-524

Bandelt HJ, Forster P, Röhl A (1999) Median-joining networks forinferring intraspecific phylogenies. Mol Biol Evol16:37-48

Beuch S (2012) Obserwacje mieszańca dzięciołów zielonego Picus viridis i zielonosiwego Picus canus w Bytomiu oraz przegląd literatury dotyczącej hybrydyzacji tych gatunków. Ptaki Śląska 19:119-126

BirdLife International (2012) Dendrocopos syriacus. In: IUCN 2013. IUCN Red List of Threatened Species. Version 2013.1. http:// www.iucnredlist.org. Downloaded on 04 September 2013

Ciach M, Fröhlich A (2013) Habitat preferences of the Syrian Woodpecker Dendrocopos syriacus in urban environments: an ambiguous effect of pollution. Bird Study 60:491-499

Ciosek J, Tomiałojé L (1982) Dzięcioł syryjski, Dendrocopos syriacus (Hempr. et Ehrenb.), ptakiem lęgowym w Polsce. Przegl Zool 26:101-109

Dray S, Dufour AB (2007) The ade4 package: implementing the duality diagram for ecologists. J Stat Softw 22:1-20

Dudzik K, Polakowski M (2011) Przypadki lęgów mieszanych oraz problematyka identyfikacji mieszańców międzygatunkowych dzięcioła białoszyjego Dendrocopos syriacus i dzięcioła dużego Dendrocopos major w Polsce. Chrońmy Przyr Ojcz 67:254-260

Ellegren H, Carlson A, Stenberg I (1999) Genetic structure and variability of white-backed woodpecker (Dendrocopos leucotos) populations in northern Europe. Hereditas 130:291-299

Excoffier L, Lischer HEL (2010) Arlequin suite ver 3.5: a new series of programs to perform population genetic analyses under Linux and Windows. Mol Ecol Resour 10:564-567

Frantz AC, Zachos FE, Kirschning J, Cellina S, Bertouille S, Mamuris Z, Koutsogiannouli EA, Burke T (2013) Genetic evidence for introgression between domestic pigs and wild boars (Sus scrofa) in Belgium and Luxembourg - a comparative approach with multiple marker systems. Biol J Linn Soc 101:104-115
Fuchs J, Pons JM, Liu L, Ericson PGP, Couloux A, Pasquet E (2013) A multi-locus phylogeny suggests an ancient hybridization event between Campephilus and melanerpine woodpeckers (Aves: Picidae). Mol Phylogenet Evol 67:78-588

Garcia-del-Rey E, Delgado G, Gonzales J, Wink M (2007) Canary Island great spotted woodpecker (Dendrocopos major) has distinct mtDNA. J Ornithol 148:531-536

Gardner MG, Fitch AJ, Bertozzi T \& Lowe AJ (2011) Rise ofthe machines - recommendations for ecologists when usingnext generation sequencing for microsatellite development.Mol Ecol Resour 11:1093-1101

Gay L, Neubauer G, Zagalska-Neubauer M, Debain C, Pons JM, David P, Crochet P-A (2007) Molecular and morphological patterns of introgression between two large white-headed gull species in a zone of recent secondary contact. Mol Ecol 7:1549-1552

Gorman G (1997) Hybridisation by Syrian Woodpecker. Br Birds 90:578

Gorman G (2004) Woodpeckers of Europe. A study of the European Picidae. Bruce Coleman, London

Goudet J (2002) fstat, a program to estimate and test gene diversitiesand fixation indices (version 2.9.3.2). http://www2. unil.ch/popgen/softwares/fstat.htm.

Grant PR, Grant BR (1992) Hybridization of bird species. Science 256:193-197

Hall TA (1999) BioEdit: a user-friendly biological sequence alignment editor and analysis program for Windows95/98/NT. Nucleic Acid Symp Ser Lond 41:95-98

Hebert PDN, Ratnasingham S, deWaard JR (2003) Barcoding animal life: cytochrome $\mathrm{c}$ oxidase subunit 1 divergences among closely related species. Proc R Soc Lond B 270:96-99

Hohenlohe PA, Amish SJ, Catchen JM, Allendorf FW, Luikart G (2011) Next-generation RAD sequencing identifies thousands of SNPs for assessing hybridization between rainbow and westslope cutthroat trout. Mol Ecol Res 11:117-122

Hubbs CL (1955) Hybridization between fish species in nature. Syst Zool 4:1-20

Johnson NK, Johnson CB (1985) Speciation in sapsuckers (Sphyrapicus): II. Sympatry, hybridization, and mate preference in $S$. ruber daggetti and $S$. nuchalis. Auk 102:1-15

Jombart T (2008) Adegenet: a R package for the multivariate analysis of genetic markers. Bioinformatics 24:1403-1405

Kajtoch $Ł$ (2012) Znaczenie karpackich dolin rzecznych dla ptaków lęgowych: przykład zlewni Stradomki i Łososiny. Chrońmy Przyr Ojcz 68:3-12

Kajtoch Ł, Brzyska-Nadachowska K, Babik W (2012) Development and characterization of microsatellite loci in the Centricnemus leucogrammus weevil. Mol Biol Rep 39:11131-11136

Keve L (1955) A balkáni fakopáncs terjeszkedése Eurpában. Aquila 59-62:299-305

Kohl I (1954) A balkáni fakopáncs és a balkáni gerle terjeszkedése Romániában. Aquila 55-58:232

Laine T (1993) A hybrid between the Great Spotted Woodpecker and the White-backed Woodpecker (in Finnish). Linnut 2:19-20

Librado P, Rozas J (2009) DnaSP v5: a software for comprehensive analysis of DNA polymorphism data. Bioinformatics 25:1451-1452

Madroño Nieto A, Pearman M (1992) Distribution, status and taxonomy of the near-threatened Black-bodied Woodpecker Dryocopus schulzi. Bird Conserv Int 2:253-272

Marisova IV (1964) On the Syrian Woodpecker (Dendrocopos syriacus) in the Ukraine. Zool J 44:1735-1737

McCarthy EM (2006) Handbook of Avian hybrids of the world. Oxford University Press, Oxford

McDevitt AD, Edwards CJ, O'Toole P, O'Sullivan P, O'Reilly C, Carden RF (2009) Genetic structure of, and hybridisation 
between, red (Cervus elaphus) and sika (Cervus nippon) deer in Ireland. Mamm Biol 74:263-273

McDevitt AD, Kajtoch L, Mazgajski TD, Carden RF, Coscia I, Osthoff C, Commbes RH, Wilson F (2011) The origins of Great Spotted Woodpeckers Dendrocopos major colonizing Ireland revealed by mitochondrial DNA. Bird Study 58:361-364

Michalczuk J, Michalczuk M (2011) Dzięcioł białoszyi Dendrocopos syriacus w Zlewni Górnej Huczwy w latach 2004-2006. Chrońmy Przyr Ojcz 67:426-432

Michalek KG, Miettinen J (2003) Dendrocopos major great spotted woodpecker. BWP Update 5:101-184

Miller AH (1955) A hybrid woodpecker and its significance in speciation in the genus Dendrocopos. Evolution 9:317-321

Moore WS, Weibel AC, Agius A (2006) Mitochondrial DNA phylogeny of the woodpecker genus Veniliornis (Picidae, Picinae) and related genera implies convergent evolution of plumage patterns. Biol J Linn Soc 87:611-624

Nadachowska K, Babik W (2009) Divergence in the face of gene flow: the case of two newts (Amphibia: Salamandridae). Mol Biol Evol 26:829-841

Pacheco NM, Congdon BC, Friesen VL (2002) The utility of nuclear introns for investigating hybridization and genetic introgression: a case study involving Brachyramphus murrelets. Conserv Genet 3:175-182

Panov E (1989) Natural hybridisation and ethological isolation in birds. Nauka, Moskow

Perktas U, Quintero E (2013) A wide geographical survey of mitochondrial DNA variation in the great spotted woodpecker complex, Dendrocopos major (Aves: Picidae). Biol J Linn Soc 108:173-188

Pritchard JK, Stephens M, Donnelly P (2000) Inference of population structure using multilocus genotype data. Genetics 155:945-959

R Development Core Team (2010) R: A Language and Environment for Statistical Computing. RFoundation for Statistical Computing, Vienna, Austria

Randler C (2002) Avian hybridization, mixed pairing and female choice. Anim Behav 63:103-119

Reister O (1894) Ornis Balcanica, II: Bulgarien. Bosnisch_Hercegovinischen Landesmuseum, Sarajevo

Rousset F (2008) GENEPOP '007: a complete reimplementation of the GENEPOP software for Windows and Linux. Mol Ecol Res 8:103-106

Rutkowski R, Mazgajski TD, Rejt $Ł$ (2006) Cross-species amplification of microsatellite loci in European woodpeckers (Picidae). Ann Zool 56:819-826

Rutkowski R, Jagołkowska P, Mazgajski TD, Rejt Ł (2007) A mitochondrial DNA control region phylogeny of the European woodpeckers Picidae. Genus (suppl.) 14:173-176

Sanz N, Araguas RM, Fernandez R, Vera M, Garcia-Marin J-L (2009) Efficiency of markers and methods for detecting hybrids and introgression in stocked populations. Conserv Gener 10:225-236

Selander RK, Giller DR (1959) Interspecific relations of woodpeckers in Texas. Wilson Bull 71:107-124
Seneviratne SS, Toews DPL, Brelsford A, Irwin DE (2012) Concordance of genetic and phenotypic characters across a sapsucker hybrid zone. J Avian Biol 43:1-12

Senn HV, Pemberton JM (2009) Variable extent of hybridisation between invasive sika (Cervus nippon) and native red deer $(C$. elaphus) in a small geographical area. Mol Ecol 18:862-876

Short LL (1982) Woodpeckers of the world. Delaware Museum of Natural History, Greenville

Skakuj M, Stawarczyk T (1994) Die Bestimmung des Blutspechts Dendrocopos syriacus und seine Ausbreitung in Mitteleuropa. Limicola 8:217-241

Tamura K, Peterson D, Peterson N, Stecher G, Nei M, Kumar S (2011) MEGA5: molecular evolutionary genetics analysis using maximum likelihood, evolutionary distance, and maximum parsimony methods. Mol Biol Evol 28:2731-2739

Thompson JD, Gibson TJ, Plewniak F, Jeanmougin F, Higgins DG (1997) The ClustalX windows interface: flexible strategies for multiple sequence alignment aided by quality analysis tools. Nucleic Acids Res 24:4876-4882

Vaha J-P, Primmer CR (2006) Efficiency of model-based Bayesian methods for detecting hybrid individuals under different hybridization scenarios and with different numbers of loci. Mol Ecol 15:63-72

Väli Ü, Dombrovski V, Treinys R, Bergmanis U, Daróczi SJ, Dravecky M, Ivanovski V, Lontkowski J, Maciorowski G, Meyburg BU, Mizera T, Zeitz R, Ellegren H (2010) Widespread hybridization between the Greater Spotted Eagle Aquila clanga and the Lesser Spotted Eagle A. pomarina (Aves: Accipitriformes) in Europe Running head: hybridization of spotted eagles in Europe. Biol J Linn Soc 100:725-736

Vila M, Robles H, Ciudad C, Olea PP, Baglione V (2008) Isolation and characterization of 12 microsatellite markers in the middlespotted woodpecker (Dendrocopos medius). Mol Ecol Res $8: 415-417$

Weibel AC, Moore WS (2002) A test of a mitochondrial gene-based phylogeny of woodpeckers (Genus Picoides) using an independent nuclear gene, B-fibrinogen intron 7. Mol Phylogenet Evol 22:247-257

Weins JJ, Servedio MR (2000) Species delimitation in systematics: inferring diagnostic differences between species. Proc R Soc Lond B 267:631-636

Wilson AC, Cann RL, Carr SM, George M, Gyllensten UB, HelmBychowski KM, Higuchi RG, Palumbi SR, Prager EM, Sage RD, Stoneking M (1985) Mitochondrial DNA and two perspectives on evolutionary genetics. Biol J Linn Soc 26:375-400

Winkler H (1971) Die artliche Isolation des Blutspechts. Picoides (Dendrocopos) syriacus. Egretta 14:1-20

Zink RM, Drovetski S, Rohwer S (2002) Phylogeographic patterns in the great spotted woodpecker Dendrocopos major across Eurasia. J Avian Biol 33:175-178 